\title{
Thyroid hormones-mediated effects of insulin on antioxidant enzymes from diabetic rat hearts
}

\author{
Kosova $\mathrm{F}^{1}$, Altan $\mathrm{N}^{2}$, Sepici $\mathrm{A}^{2}$, Engin $\mathrm{A}^{3}$, Kocamanoglu $\mathrm{N}^{2}$ \\ Celal Bayar University School of Health, Manisa, Turkey. fundakosova@gmail.com
}

\begin{abstract}
Free radicals, oxidative stress, and antioxidants have become commonly used terms in modern discussion of disease mechanisms. Accumulation of evidence suggests that toxic oxygen-derived reactive free radicals (superoxide, peroxide and hydroxyl radicals) play a crucial role in etiology of diabetes and its complication. Thus, it was aimed to determine the role of thyroid hormones in reversal of antioxidatant enzyme activities and lipid peroxidation alterations observed in experimentally induced diabetic rat hearts. The present study investigates the antioxidant enzyme activities such as SOD, CAT, GSH-Px and lipid peroxidation products in cardiac tissues of streptozotosin (STZ)-induced diabetic rats before and after thyroidectomy. Our results showed that CAT, GPx enzyme activities and FOX, MDA levels were increased $(p<0.05)$ and SOD, Mn-SOD, Cu-SOD activities were decreased $(p<0.05)$ during diabetes, hypothyroidism and hypothyroidism with diabetes, which can be regulated in different percentages with treatment of insulin and various doses of thyroid hormone $(p<0.05)$. In conclusion, in this study, the possible contribution of thyroid hormones to the insulin effect of normalizing the induced diabetic changes in cardiac tissue and serum of rat has been seen (Tab. 5, Ref. 32). Full Text in PDF www.elis.sk.

Key words: diabetes mellitus, thyroid hormone, superoxide dismutase (SOD), glutathione peroxidase (GPx), catalase (CAT), malondialdehyde (MDA), ferrous oxidation in xylenol orange (FOX).
\end{abstract}

Free radicals, oxidative stress, and antioxidants have become commonly used terms in modern discussion of disease mechanisms (1). Accumulating evidence suggests that toxic oxygenderived reactive free radicals (superoxide, peroxide and hydroxyl radicals) play a crucial role in etiology of diabetes and its complication (2-5).

Increased amounts of glucose can also be transported intracellularly and metabolized to increase the flux through the sorbitol patway, change redox potential or alter the signal transduction patways (6-8).

In the presence of diabetes, persistent hyperglycemia causes an increased production of free radicals via both auto-oxidation of glucose (9) and enzymatic protein glycation that may lead to the disruption of cellular function and oxidative damage of membranes ${ }^{2}$. Free radicals affect the cellular components such as lipid, protein, DNA and carbohydrates of which lipids are the most sensitive part (10). The concentration of these reactive oxygen species are controlled by antioxidant enzymes, namely

${ }^{1}$ Celal Bayar University School of Health, Manisa, Turkey, ${ }^{2}$ Gazi University, School of Medicine, Department of Medical Biochemistry, Ankara, Turkey, and ${ }^{3}$ Gazi University, School of Medicine, Department of Surgery, Ankara, Turkey

Address for correspondence: F. Kosova, Doc Dr, Celal Bayar University School of Health, Manisa, Turkey. Phone: +0.236 .2391318$

Acknowledgements: This study was presented at the $30^{\text {th }}$ Annual Meeting of the European Thyroid Association, September 18-22, 2004, Istanbul. superoxide dismutase (SOD), catalase (CAT), glutathione peroxidase (GSH-Px) and nonenzymatic scavengers like reduced glutathione (GSH). Alterations in antioxidant enzyme activities have been reported in diabetes, and thus the tissue antioxidant status seems to emerge as an important factor in the etiology of diabetic complications (cardiomyopathy, retinopathy and nephropathy). Since the lack of insulin is the main drawback of diabetes, attempts have been made to normalize the diabetesinduced myocardial antioxidant enzyme alterations by insulin replacement therapy. Insulin replacement therapy has been shown to be successful in reversing the myocardial antioxidant enzyme alterations into normal $(2,9)$.

An emerging body of evidence suggests that reactive oxygenderived radicals play a crucial role in diabetogenic effects of streptozotosin (STZ). The activity of antioxidant enzymes in pancreas is low relative to the situation in tissue, making it particularly vulnerable to oxygen radical attack (3-5). On the other hand, an induction of diabetes by streptozotocin (stz) has been shown to produce a hypothyroid state in experimental animals $(11,12)$. It is thus possible that the diabetes-induced cardiac antioxidant enzyme alterations could partly result from hypothyroidism which is seen during diabetes.

Hence, present study investigates the antioxidant enzyme activities such as SOD, CAT, GSH-Px and lipid peroxidation products in cardiac tissues of stz diabetic rats before and after thyroidectomy. Thus, it was aimed to determine the role of thyroid hormones in reversing the antioxidatant enzyme activities and lipid peroxidation alterations observed in experimentally induced-diabetic rat hearts. 


\section{Materials and methods}

The study protocol was reviewed and approved by the Animal Care Committee and Surgical Research Center of Gazi University Faculty of Medicine (GUDAM). Guiding principles for experimental procedures found in the Declaration of Helsinki of the World Medical Association regarding animal experimentation were followed in the study. We focused on the possible effect of insulin treatment on antioxidant enzyme activities in hypothyroid and hypothyroid diabetic heart tissues in male albino rats (150-200 g of body weight). The experimental group was injected intraperitoneally with streptozotocin (STZ) (freshly dissolved in saline, 55 $\mathrm{mg} / \mathrm{kg}$ ) whereas the control group was injected with saline only. Three days after the administration, the rats were fasted overnight and blood glucose levels were determined. The animals which had basal glycemia levels of $400 \mathrm{mg} / \mathrm{dl}$ were used in the experiments. Animals had free access to food and water after stz injection.

Rats were assigned to eight groups: Group 1: control, Group 2: diabetes, Group 3: diabetes + insulin (five weeks after diabetes induction, some of the rats were given insulin, 7-10 U/kg day, Insulatard- HM® Penfill@, Novo Nordisk, 100 IU/ml NPH, subcutaneously), Group 4: surgical thyroidectomized control rats, Group 5: thyroidectomized rats + diabetes (diabetes was induced 3 weeks after the surgical operation at hypothyroid state), Group 6: thyroidectomized rats + diabetes + insulin (after diabetes inductions, rats were treated with insulin for five weeks, 7-10 U/kg day, subcutaneously), Group 7: thyroidectomized rats + diabetes + insulin + thyroid hormone (after diabetes induction, rats were treated both with insulin (7-10 U/kg day, subcutaneously) and thyroid hormone, levothyroxin sodium, $2.5 \mu \mathrm{g} / \mathrm{kg}$, Tefor ${ }^{\circledR}$ (Organon) for five weeks), Group 8: thyroidectomized rats + diabetes + insulin + thyroid hormone (after diabetes induction, rats were treated both with insulin (7-10 U/kg day, subcutaneously) and thyroid hormone, levothyroxin sodium, $5 \mu \mathrm{g} / \mathrm{kg}$, Tefor ${ }^{\circledR}$ (Organon) for five weeks).

Body weights were obtained before treatment and prior to sacrifice. Blood samples were collected from the tail vein and with cardiac puncture at the time of sacrifice. Blood glucose levels were determined by glucose oxidase enzymatic assay (Glucometer, Ames, Miles Laboratories Inc, Elkhart, IN, USA). Free $\mathrm{T}_{3}\left(\mathrm{FT}_{3}\right)$, free $\mathrm{T}_{4}\left(\mathrm{FT}_{4}\right)$, total $\mathrm{T}_{3}\left(\mathrm{~T}_{3}\right)$ and total $\mathrm{T}_{4}\left(\mathrm{~T}_{4}\right)$ levels were measured in the serum by TOSOH automated analyzer (TOSOH AIA-21, TOSOH Bioscience, N.V., Tessenderlo, Belgium). HbA1c levels were analyzed in the day of experiments by Olympus autoanalyzer (Olympus AU 400 analyzer, Olympus Diagnostica GmbH, Clarecastle, Ireland) depending on the turbidimetric inhibition of hemolyzed blood samples.

The rats were anesthetized using ketamine hydrochloride (ketalar ${ }^{\circledR}$, Eczacibasi, Turkey). The tissues were briefly washed in ice-cold $0.9 \%$ saline (w/v), frozen in liquid nitrogen and stored at $-70{ }^{\circ} \mathrm{C}$ until the subsequent protein and enzyme assays.

Protein concentration was measured in tissue homogenate by the method used by Lowry (13), using bovine albumin standard.

For SOD assay, tissue samples were homogenized in ratio of 1/10 in phosphate buffer ( $\mathrm{pH}: 7.4$ ) and the supernatant was care- fully separated, then $3 / 5(\mathrm{v} / \mathrm{v})$ chloroform and ethanol were added. This mixture was centrifuged at $5000 \mathrm{x}$ g for $2 \mathrm{~h}$. The supernatant was used for assay of superoxide dismutase. This assay for superoxide dismutase activity involves xanthine oxidase used as superoxide generator (14).

The results were expressed as unit per mg protein tissue. One unit of SOD is defined as an amount of protein inhibiting the rate of NBT reduction by $50 \%$.

To determine GSH-Px activity, tissue samples were homogenized in ratio of $1 / 10$ in phosphate buffer $(\mathrm{pH} 7.0$ ) containing 0.5 $\mathrm{mM}$ EDTA and then centrifuged at $2000 \mathrm{x} \mathrm{g}$ for $15 \mathrm{~min}$. Glutathione peroxidase activity was measured by a coupled modification of the coupled assay procedure of Paglia and Valentine (15). The results were expressed as nmoles of NADPH oxidized per min per mg protein.

Tissue catalase activity was measured by the method used by Aebi (16). Tissue samples were homogenized in phosphate buffer ( $\mathrm{pH} 7.0$ ) and centrifuged at $1900 \mathrm{x}$ g for $15 \mathrm{~min} . \mathrm{H}_{2} \mathrm{O}_{2}$ was added to supernatant and the decreasing of absorbance was measured at $240 \mathrm{~nm}$ for $3 \mathrm{~min}$. The results were expressed as Katal $/ \mathrm{mg}$ protein.

The levels of malondialdehyde were determined in tissue samples homogenized in ratio of 1:10 in $1.5 \%(\mathrm{w} / \mathrm{v})$ cold KCI solution, using thiobarbitüric acid method (17) and the results were obtained in $\mathrm{nmol} / \mathrm{g}$ tissue wt.

To determine FOX activity, tissue samples were homogenized in ratio of 1/10 in cold methanol ( $\mathrm{pH}$ 7.4) and then centrifuged at $1000 \mathrm{x}$ g for $15 \mathrm{~min}$. FOX activity was measured by a coupled modification of the coupled assay procedure of Hermes-Lima (18). This study shows that lipid hydroperoxides can be effectively quantified in animal tissue extracts using an assay based on the formation of a $\mathrm{Fe}$ (III) xylenol orange complex. Addition of $\mathrm{H}_{2} \mathrm{O}_{2}$, cumene hydroperoxides, or metholic tissue extracts to an acidic mixture containing $0.25 \mathrm{mM}$ Fe (II) and $0.1 \mathrm{mM}$ xylenol orange resulted in the formation of a broad Fe (III) xylenol orange peak at $440 \mathrm{~nm}$. Complex formation measured at $580 \mathrm{~nm}$ was saturable with both xylenol orange and Fe (II) concentration and the results were expressed as nmoles/g tissue wt.

Non-parametric methods were performed in the cross-sectional analysis of biomedical data (Mann-Whitney U test). Two-tailed probability ( $p$ ) values were calculated throughout, and statistical significance was defined as $p<0.05$. All analyses were performed by statistical software SPSS 10.0 .

\section{Results}

In the present study, rats demonstrated polyphagia, polydipsia and stable hyperglycemia after STZ treatment for 5 weeks as determined by measuring blood glucose levels every 3 days. Body weights were obtained before treatment and prior to sacrifice. Body weight measurements revealed a significant difference in all groups compared to group 2, and also groups 2 and 4 revealed a significant difference compared to groups 1 and 5 at the time of sacrifice $(\mathrm{p}<0.05)$. In group 6 , body weight measurements were unchanged compared to groups 3,7 and $8(p<0.05)$. Furthermore, blood glucose determination showed a significant hyperglycemia 
Tab. 1. Changes in body weight, blood glucose and HbA1c concentration in all groups (values represent mean \pm SD).

\begin{tabular}{|c|c|c|c|}
\hline Groups & $\begin{array}{l}\text { Body Weight } \\
(\mathrm{g})\end{array}$ & $\begin{array}{l}\text { Blood Glucose Concentration } \\
(\mathrm{mg} / \mathrm{dl})\end{array}$ & $\begin{array}{l}\mathrm{HbA} 1 \mathrm{c} \\
(\%)\end{array}$ \\
\hline Group $1(n=10)$ Control & $235.0 \pm 35.3$ & $109.5 \pm 4.6$ & $4.82 \pm 0.3$ \\
\hline Group $2(n=9)$ Diabetes (DM) & $159.0 \pm 32.2^{\text {acd }}$ & $424.0 \pm 22.8^{\mathrm{ad}}$ & $12.11 \pm 0.6^{\mathrm{acd}}$ \\
\hline Group $3(n=6)$ DM \pm Insülin (I) & $232.1 \pm 48.5^{\mathrm{bc}}$ & $108.0 \pm 18.2^{\mathrm{bc}}$ & $4.24 \pm 0.07^{\mathrm{bcd}}$ \\
\hline Group 4 ( $n=9$ Thyroidectomy (Thy) & $285.0 \pm 34.7^{\mathrm{abcd}}$ & $115.8 \pm 20.1^{\mathrm{bc}}$ & $4.64 \pm 0.2^{\mathrm{bcd}}$ \\
\hline Group $5(n=8)$ Thy \pm DM & $235.0 \pm 22.7^{\mathrm{b}}$ & $487.4 \pm 35.7^{\mathrm{ad}}$ & $6.01 \pm 0.8^{\mathrm{abd}}$ \\
\hline Group $6(n=9)$ Thy $\pm D M \pm I$ & $239.5 \pm 32.9^{\mathrm{b}}$ & $109.2 \pm 9.6^{\mathrm{bc}}$ & $5.38 \pm 0.8^{\mathrm{abc}}$ \\
\hline Group $7(\mathrm{n}=4)$ Thy $\pm \mathrm{DM} \pm \mathrm{I} \pm$ Thyroid $\mathrm{hr}(\mathrm{T} 4,2.5 \mu \mathrm{g} / \mathrm{kg})$ & $225.0 \pm 5.7^{b}$ & $92.7 \pm 4.1^{\text {bcd }}$ & $4.76 \pm 0.15^{\mathrm{bc}}$ \\
\hline Group $8(\mathrm{n}=6)$ Thy $\pm \mathrm{DM} \pm \mathrm{I} \pm$ Thyroid $\mathrm{hr}(\mathrm{T} 4,5 \mu \mathrm{g} / \mathrm{kg})$ & $232.3 \pm 2.6^{b}$ & $92.7 \pm 3.1^{\text {bcd }}$ & $4.92 \pm 0.13^{\text {bcd }}$ \\
\hline
\end{tabular}

$\mathrm{N}=$ number of rats,

a: significant compared to Group 1, control $(\mathrm{p}<0.05)$

b: significant compared to Group 2, diabetes $(\mathrm{p}<0.05)$

c: significant compared to Group 5 , thyroidectomized and diabetes $(\mathrm{p}<0.05)$

d: significant compared to Group 6 , Thy $\pm \mathrm{DM} \pm \mathrm{I}(\mathrm{p}<0.05)$

Tab. 2. Serum thyroid hormone levels of all groups (values represent mean \pm SD).

\begin{tabular}{|c|c|c|c|c|}
\hline Groups & FT3 ( $\mathrm{pmol} / \mathrm{L})$ & FT4 ( $\rho \mathrm{mol} / \mathrm{L})$ & T3 (ng/ml) & $\mathrm{T} 4$ (nmol/L) \\
\hline Group $1(n=10)$ Control & $3.87 \pm 0.63^{\text {bcd }}$ & $19.84 \pm 2.15^{\text {bcd }}$ & $0.64 \pm 0.02^{\mathrm{bcd}}$ & $40.11 \pm 3.30^{\mathrm{bcd}}$ \\
\hline Group $2(n=10)$ Diabetes (DM) & $1.39 \pm 0.35^{\mathrm{ad}}$ & $7.54 \pm 3.17^{\mathrm{a}}$ & $0.28 \pm 0.07^{\mathrm{a}}$ & $19.47 \pm 7.23^{\text {acd }}$ \\
\hline Group $3(n=7) \quad D M \pm$ Insulin (I) & $4.33 \pm 0.77^{\mathrm{bcd}}$ & $28.73 \pm 4.15^{\mathrm{abcd}}$ & $0.41 \pm 0.11^{\mathrm{abcd}}$ & $35.38 \pm 4.06^{\mathrm{abcd}}$ \\
\hline Group $4(n=10)$ Thyroidectomy (Thy) & $1.46 \pm 0.08^{\mathrm{ad}}$ & $9.14 \pm 2.06^{\mathrm{acd}}$ & $0.29 \pm 0.09^{\mathrm{a}}$ & $15.54 \pm 4.15^{\mathrm{acd}}$ \\
\hline Group $5(n=8)$ Thy \pm DM & $1.39 \pm 0.26^{\mathrm{ad}}$ & $4.20 \pm 2.31^{\mathrm{abd}}$ & $0.28 \pm 0.05^{\mathrm{a}}$ & $6.54 \pm 0.01^{\mathrm{abd}}$ \\
\hline Group $6(n=9)$ Thy \pm DM $\pm I$ & $2.63 \pm 0.98^{\mathrm{abcd}}$ & $7.56 \pm 2.12^{\mathrm{a}}$ & $0.26 \pm 0.05^{\mathrm{a}}$ & $20.06 \pm 5.24^{\mathrm{acd}}$ \\
\hline Group $7(\mathrm{n}=4)$ Thy $\pm \mathrm{DM} \pm \mathrm{I} \pm$ Thyroid hr $(\mathrm{T} 4,2.5 \mu \mathrm{g} / \mathrm{kg})$ & $5.10 \pm 0.83^{\mathrm{abcd}}$ & $26.52 \pm 3.00^{\mathrm{abcd}}$ & $0.46 \pm 0.02^{\mathrm{abcd}}$ & $46.27 \pm 6.81^{\text {bcd }}$ \\
\hline
\end{tabular}

$\mathrm{N}=$ number of rats

a: significant compared to Group 1, control $(\mathrm{p}<0.05)$

b: significant compared to Group 2, diabetes $(\mathrm{p}<0.05)$

c: significant compared to Group 5, thyroidectomized and diabetes $(\mathrm{p}<0.05)$

d: significant compared to Group 6, Thy $\pm \mathrm{DM} \pm \mathrm{I}(\mathrm{p}<0.05)$

Tab. 3. SOD, Cu-Zn SOD, MnSOD levels of heart tissues (values represent mean \pm SD).

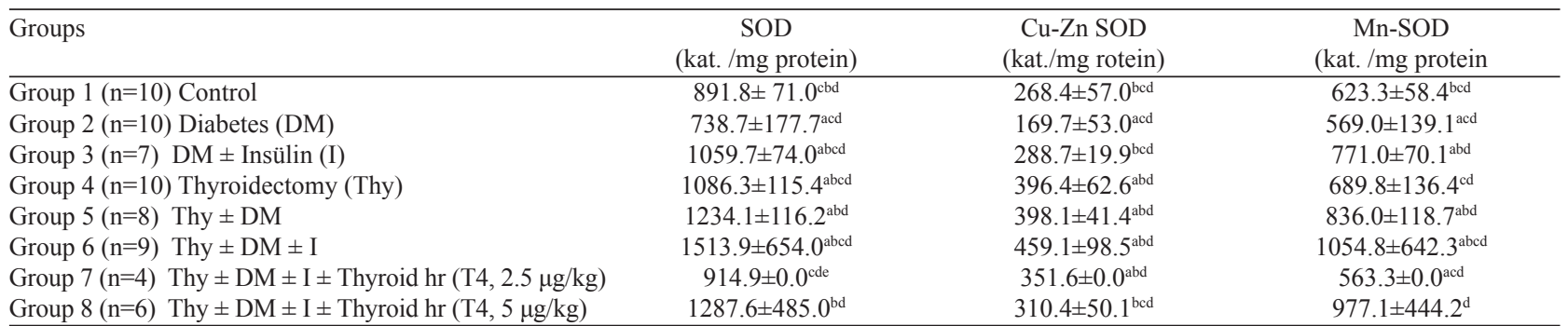

$\mathrm{N}=$ number of rats

a: significant compared to Group 1, control $(\mathrm{p}<0.05)$

b: significant compared to Group 2, diabetes $(\mathrm{p}<0.05)$

c: significant compared to Group 5 , thyroidectomized and diabetes $(\mathrm{p}<0.05)$

$\mathrm{d}$ : significant compared to Group 6, Thy $\pm \mathrm{DM} \pm \mathrm{I}(\mathrm{p}<0.05)$

in groups 2 and 5 compared to group $1(\mathrm{p}<0.05)$. In group 3, blood glucose levels were unchanged while the blood glucose levels in groups 7 and 8 were significantly decreased compared to group 6 $(\mathrm{p}<0.05)$. HbA1c levels were significantly increased in groups 2 and 5 compared to group $1(\mathrm{p}<0.05)$. However, HbA1c levels were significantly decreased in groups 3, 7 and 8 compared to group 6 $(\mathrm{p}<0.05)$. Table 1 summarizes the mean changes in bodyweight, blood glucose concentrations and $\mathrm{HbA} 1 \mathrm{c}$ levels of all groups.

Serum Free $\mathrm{T}_{3}\left(\mathrm{FT}_{3}\right)$, free $\mathrm{T}_{4}\left(\mathrm{FT}_{4}\right)$, total $\mathrm{T}_{3}\left(\mathrm{~T}_{3}\right)$ and total $\mathrm{T}_{4}$ $\left(\mathrm{T}_{4}\right)$ levels were significantly decreased $(\mathrm{p}<0.05)$ in group 2 after 5 weeks of diabetes, and serum $\mathrm{FT}_{3}$ levels were normalized in group 3 depending on insulin treatment compared to control group 1. In group $5, \mathrm{FT}_{4}$ and $\mathrm{T}_{4}$ levels were significantly decreased after the induction of diabetes $(p<0.05)$ compared to group 4 . In groups 7 and 8 , thyroid hormone levels significantly increased after the treatment $(\mathrm{P}<0.05) . \mathrm{FT}_{3}, \mathrm{FT}_{4}, \mathrm{~T}_{3}$ and $\mathrm{T}_{4}$ levels were significantly increased in groups 3,7 and 8 compared to group $6(\mathrm{p}<0.05)$. Table 2 summarizes the mean changes of serum $\mathrm{FT}_{3}, \mathrm{FT}_{4}, \mathrm{~T}_{4}$ and $\mathrm{T}_{3}$ levels in all groups.

In the present study, group 2 (SOD, Cu-Zn SOD, Mn-SOD $\mathrm{P}<0.05)$ and group $7(\mathrm{Mn}-\mathrm{SOD} \mathrm{p}<0.05)$ were significantly decreased; groups 3, 4, 5 and 6 (SOD, Cu-Zn SOD, Mn-SOD p<0.05) and group $7(\mathrm{Cu}-\mathrm{Zn} \mathrm{SOD}, \mathrm{p}<0.05)$ were significantly increased; group 7 (SOD, $\mathrm{p}<0.05$ ) and group 8 (SOD, Cu-Zn SOD, Mn-SOD $\mathrm{p}<0.05$ ) were unchanged, compared to respective group 1 (con- 
183-188

Tab. 4. GPx and catalase levels of heart tissues (values represent mean \pm SD).

\begin{tabular}{|c|c|c|}
\hline Groups & $\begin{array}{c}\text { GPx } \\
\text { (nmol oxidized NADPH/dk/mg protein) }\end{array}$ & $\begin{array}{c}\text { Catalase } \\
\text { (Kat./mg prot) }\end{array}$ \\
\hline Group $1(n=10)$ Control & $88.0 \pm 28.9^{\text {bcd }}$ & $0.22 \pm 0.1^{\text {bcd }}$ \\
\hline Group $2(n=10)$ Diabetes (DM) & $205.3 \pm 72.9^{\mathrm{ad}}$ & $0.39 \pm 0.1^{\text {acd }}$ \\
\hline Group $3(n=7) \quad D M \pm$ Insülin (I) & $81.3 \pm 16.4^{\mathrm{bcd}}$ & $0.22 \pm 0.1^{\mathrm{bcd}}$ \\
\hline Group $4(n=10)$ Thyroidectomy (Thy) & $88.8 \pm 25.3^{\text {bcd }}$ & $0.28 \pm 0.05^{\mathrm{cd}}$ \\
\hline Group $5(n=8)$ Thy \pm DM & $186.4 \pm 26.9^{\mathrm{ad}}$ & $0.56 \pm 0.19^{\text {abd }}$ \\
\hline Group $6(n=9)$ Thy $\pm D M \pm I$ & $126.8 \pm 32.0^{\mathrm{abc}}$ & $0.45 \pm 0.08^{\mathrm{ab}}$ \\
\hline Group $8(\mathrm{n}=6)$ Thy $\pm \mathrm{DM} \pm \mathrm{I} \pm$ Thyroid hr $(\mathrm{T} 4,5 \mu \mathrm{g} / \mathrm{kg})$ & $79.5 \pm 23.4^{\mathrm{bcd}}$ & $0.13 \pm 0.02^{\text {bed }}$ \\
\hline
\end{tabular}

$\mathrm{n}=$ number of rats

a: significant compared to Group 1, control $(\mathrm{p}<0.05)$

b: significant compared to Group 2, diabetes $(\mathrm{p}<0.05)$

c: significant compared to Group 5, thyroidectomized and diabetes $(\mathrm{p}<0.05)$

d: significant compared to Group 6 , Thy $\pm \mathrm{DM} \pm \mathrm{I}(\mathrm{p}<0.05)$

Tab. 5. FOX and MDA levels of heart tissues (values represent mean \pm SD).

\begin{tabular}{lcc}
\hline Groups & MDA $(\mu \mathrm{mol} / \mathrm{g}$ tissue $)$ & FOX $(\mathrm{nmol} / \mathrm{g}$ tissue $)$ \\
\hline Group 1 ( $\mathrm{n}=10)$ Control & $0.13 \pm 0.04^{\mathrm{bc}}$ & $983.4 \pm 226.2^{\mathrm{bcd}}$ \\
Group 2 $(\mathrm{n}=10)$ Diabetes $(\mathrm{DM})$ & $0.19 \pm 0.1^{\mathrm{ad}}$ & $1304.4 \pm 302.9^{\mathrm{ad}}$ \\
Group 3 $(\mathrm{n}=7)$ DM \pm Insülin $(\mathrm{I})$ & $0.14 \pm 0.04^{\mathrm{bc}}$ & $1042.2 \pm 268.6^{\mathrm{bcd}}$ \\
Group $4(\mathrm{n}=10)$ Thyroidectomy (Thy) & $0.15 \pm 0.06^{\mathrm{bc}}$ & $936.4 \pm 283.4^{\mathrm{bcd}}$ \\
Group 5 $(\mathrm{n}=8)$ Thy $\pm \mathrm{DM}$ & $0.22 \pm 0.06^{\mathrm{ad}}$ & $1582.6 \pm 752.6^{\mathrm{ad}}$ \\
Group 6 $(\mathrm{n}=9)$ Thy $\pm \mathrm{DM} \pm \mathrm{I}$ & $0.14 \pm 0.07^{\mathrm{bc}}$ & $888.2 \pm 167.9^{\mathrm{bc}}$ \\
Group 7 $(\mathrm{n}=4)$ Thy $\pm \mathrm{DM} \pm \mathrm{I} \pm$ Thyroid $\mathrm{hr}(\mathrm{T} 4,2.5 \mu \mathrm{g} / \mathrm{kg})$ & $0.15 \pm 0.08^{\mathrm{abc}}$ & $1191.2 \pm 97.7^{\mathrm{bcc}}$ \\
Group 8 $(\mathrm{n}=6)$ Thy $\pm \mathrm{DM} \pm \mathrm{I} \pm$ Thyroid $\mathrm{hr}(\mathrm{T} 4,5 \mu \mathrm{g} / \mathrm{kg})$ & $0.11 \pm 0.05^{\mathrm{bcd}}$ & $868.3 \pm 69.4^{\mathrm{bc}}$ \\
\hline
\end{tabular}

$\mathrm{n}=$ number of rats

a: significant compared to Group 1, control $(\mathrm{p}<0.05)$

b: significant compared to Group 2, diabetes $(\mathrm{p}<0.05)$

c: significant compared to Group 5, thyroidectomized and diabetes $(\mathrm{p}<0.05)$

d: significant compared to Group 6, Thy $\pm \mathrm{DM} \pm \mathrm{I}(\mathrm{p}<0.05)$

trol). Groups 3, 4, 5 and 6 (SOD, Cu-ZnSOD, Mn-SOD p <0.05) and groups 7 and 8 (SOD, Mn-SOD $<<0.05)$ were significantly increased, while groups 7 and $8(\mathrm{Cu}-\mathrm{ZnSOD}, \mathrm{p}<0.05)$ were unchanged compared to respective group 2 (Diabetes). Groups 3, 4 and 7 (SOD, $\mathrm{p}<0.05$ ) were significantly decreased; group 6 (SOD, $\mathrm{p}<0.05$ ) was significantly increased, while group 8 ( $S O D, p<0.05$ ), was unchanged, compared to respective group 5 (Thyroidectomy + Diabetes). Groups 3 and $8(\mathrm{Cu}-\mathrm{ZnSOD}, \mathrm{p}<0.05)$ were significantly decreased, while other groups $(\mathrm{Cu}-\mathrm{ZnSOD}, \mathrm{p}<0.05)$ were unchanged compared to respective group 5 (Thyroidectomy + Diabetes). Groups 4 and $7(\mathrm{Mn}-\mathrm{SOD} \mathrm{p}<0.05)$ were significantly decreased; group $6(\mathrm{Mn}-\mathrm{SOD} \mathrm{p}<0.05)$ was significantly increased, while other groups $(\mathrm{Mn}-\mathrm{SOD}, \mathrm{p}<0.05)$ were unchanged compared to respective group 5 (Thyroidectomy + Diabetes). Furthermore, groups 3, 7 and 8 (SOD, Cu-ZnSOD, Mn-SOD p<0.05) were significantly decreased compared to respective group 6 (Thy \pm DM \pm I) (Tab. 3).

Groups 2, 5 and 6 (GPx p<0.05) were significantly increased; group 7 (GPx p<0.05) was significantly decreased, while groups 3,4 and $8(\mathrm{GPx} p<0.05)$ were unchanged compared to respective group 1 (control). Groups 3, 4, 6, 7 and 8 (GPx p<0.05) were significantly decreased, while group 5 (GPx $\mathrm{p}<0.05)$ was unchanged compared to respective group 2 (Diabetes). Groups 3, 4, 6, 7 and 8 (GPx $\mathrm{p}<0.05)$ were significantly decreased compared to respective group 5 (Thyroidectomy + Diabetes). Furthermore, groups 3 , 7 and $8(\mathrm{GPx} p<0.05)$ were significantly decreased compared to respective group 6 (Thy $\pm \mathrm{DM} \pm \mathrm{I})$ (Tab. 4).
CAT activities in heart tissue in groups 2,5 and $6($ CAT $\mathrm{p}<0.05)$ were significantly increased; in group 7 (CAT $p<0.05$ ), they were significantly decreased, while groups 3,4 and 8 (CAT p<0.05) were unchanged compared to respective group 1 (control). Groups 5 and $6($ CAT $\mathrm{p}<0.05)$ were significantly increased; groups 3,7 and 8 (CAT $\mathrm{p}<0.05)$ were significantly decreased while group 4 $(\mathrm{CAT} \mathrm{p}<0.05)$ was unchanged, compared to respective group 2 ( Diabetes). Groups 3, 4, 7 and 8 (CAT p $<0.05$ ) were significantly decreased while group 6 (CAT $\mathrm{p}<0.05)$ was unchanged compared to respective group 5 (Thyroidectomy + Diabetes). Furthermore, groups 3,7 and $8($ CAT $p<0.05)$ were significantly decreased compared to respective group 6 (Thy $\pm \mathrm{DM} \pm \mathrm{I}$ ) (Tab. 4).

Groups 2, 5 and 7 (MDA p $<0.05)$ were significantly increased while groups 3, 4, 6 and 8 (MDA $\mathrm{p}<0.05$ ) were unchanged compared to respective group 1 (control). Groups 3, 4, 6, 7 and 8 $(\mathrm{MDA} \mathrm{p}<0.05)$ were significantly decreased while group 5 (MDA $\mathrm{p}<0.05$ ) was unchanged compared to respective group 2 (Diabetes). Groups 3, 4, 6, 7 and 8 (MDA $<0.05$ ) were significantly decreased compared to respective group 5 (Thyroidectomy + Diabetes). Furthermore, groups 3 and 7 (MDA $\mathrm{p}<0.05$ ) were unchanged while group 8 was significantly decreased compared to respective group 6 (Thy $\pm \mathrm{DM} \pm \mathrm{I})($ Tab. 5).

FOX activities in heart tissue in groups 2, 5 and 7 (FOX $\mathrm{p}<0.05$ ) were significantly increased while groups $3,4,6$ and 8 (FOX $\mathrm{p}<0.05$ ) were unchanged, compared to respective group 1 (control). Groups 3, 4, 6, 7 and 8 (FOX $\mathrm{p}<0.05)$ were significantly decreased while group $5($ FOX $p<0.05)$ was unchanged 
compared to respective group 2 (Diabetes). Groups 3, 4, 6, 7 and $($ FOX $\mathrm{p}<0.05)$ were significantly decreased compared to respective group 5 (Thyroidectomy + Diabetes). Furthermore, groups 3 and 7 $($ FOX $\mathrm{p}<0.05)$ were significantly increased while group 8 was unchanged compared to respective group 6 (Thy $\pm \mathrm{DM} \pm \mathrm{I})$ (Tab. 5).

\section{Discussion}

Oxidative stress has been proposed as the major source of events causing late complications in patients with diabetes mellitus. Sensitive and reliable laboratory tools for detecting oxidative stress are a prerequisite for animal experimental models and studies in human diabetes (19).

Alterations in antioxidant enzyme activities have been reported in diabetes and thus the tissue antioxidant status seems to emerge as an important factor in the etiology of diabetic complications. Serum levels of thyroid hormones are also significantly reduced in streptozotocin-induced diabetic rats but they return to normal after administration of insulin (20).

Hyperglycemia is the primary clinical manifestation of diabetes, and is associated with the development of several clinical complications. Some blood components such as HbA1c and glucose levels are used as indicators of the metabolic status of diabetic individuals (21). In the present study, the levels of $\mathrm{HbA} 1 \mathrm{c}$ and glucose were significantly increased in the diabetic group. Recent studies have shown that the activation of AMP-dependent kinase protein (AMPK) is responsible for the increase in glucose uptake in muscle (21).

In the present study, the activity of SOD, Cu-ZnSOD and MnSOD decreased in diabetic heart, hypothyroidism and hypothyroidism with diabetes, which can be regulated in different percentages with the treatment of insulin and various doses of thyroid hormone. The decrease in SOD activity observed in the heart could be due to glycation of the enzyme and/or result from excessive accumulation of free radicals (6).

The increased CAT activity observed in the heart of diabetic rats agrees with the findings of Asayama et al (22), Godin et al (5) and Bukan et al (6). Insulin deficiency promotes $\beta$ - oxidation of fatty acids with resulting $\mathrm{H}_{2} \mathrm{O}_{2}$ formation $(6,23)$. The elevation of CAT activity may be due to a compensatory increase in endogenous $\mathrm{H}_{2} \mathrm{O}_{2}$ production in the heart (6). In our study, we observed that CAT levels in insulin-treated groups (Tab. 4) (group 3) were not effective, and this alteration was increased in hypothyroid-diabetic groups (Tab. 4) (group 6), which indicates that the insulin treatment can regulate CAT levels related to thyroid hormone levels.

The results suggest that GPx is primarily responsible for the decomposition of $\mathrm{H}_{2} \mathrm{O}_{2}$. Jones et al (24) and Nicholls (25) reported that at low $\mathrm{H}_{2} \mathrm{O}_{2}$ generation rates, GPx plays a key role in $\mathrm{H}_{2} \mathrm{O}_{2}$ metabolism, while at higher $\mathrm{H}_{2} \mathrm{O}_{2}$ generation rates, the role of CAT becomes more important. In the present study, the GPx activity increased in diabetic heart, hypothyroidism and hypothyroidism with diabetes, which can be regulated at different percentages with the treatment of insulin and various doses of thyroid hormone.

Free radicals affect the cell components such as lipid, protein, DNA and carbohydrates, but of which lipid is the most sensitive part. The increase in free radicals in many diseases is suggested to be caused by increased lipid peroxidation and damaged antioxidant defense system (26).

The increase in MDA levels in spite of increased activity of antioxidant enzymes could be due to increased production of oxygen free radicals in amount exceeding the capacity of antioxidant enzymes to metabolize them (26).

$\mathrm{H}_{2} \mathrm{O}_{2}$ is postulated to be a biomarker of oxidative stress, a phenomenon of considerable clinical interest as oxidative stress is associated with a number of clinical conditions including diabetes mellitus (27). Hydrogen peroxide production was increased by insulin and reduced by thyroid hormones and glucocorticoids. The changes in antioxidant enzyme activities caused by these hormones in macrophages may indicate important mechanisms for establishing the impaired immune function in endocrine pathologies (28). Plasma hydroperoxide concentration was previously estimated by FOX-2 assay (29).

The main findings of our recent study are increased rat heart MDA and FOX levels during the diabetes, hypothyroidism and hypothyroidism with diabetes, which can be regulated at various percentages with insulin and various doses of thyroid hormone. Moreover, it was observed that the data were regulated by insulin treatment. The results obtained in this study are in general agreement with those of our earlier studies (6).

During diabetic condition, thyroid hormones (T3 and T4) are suppressed and it is suggested that serum insulin levels regulate the basal metabolic rate (28). These decreases reflected the significant reduction in T3/T4 ratio in the diabetic group. T3 and T4 depletions in serum might be due to the lack of thyroid binding proteins needed for their transport (28). Karasu et al (29) demonstrated that thyroid hormones were needed for insulin to reverse the diabetesinduced alterations in heart tissue. In another study with experimental diabetic rats, the decreased levels of thyroid hormones were maintained by insulin treatment (30). In our previous study, DNA damage could not be possibly controlled with insulin treatment but in surgically thyroidectomized rats with diabetes treated with both with insulin and appropriate thyroid hormone, the doses were succeeded (31). In our other studies (32), the stz-induced diabetic group data support this knowledge while showing a decrease in all serum thyroid hormone parameters in diabetes groups and an increase after insulin treatment. In addition to those, also in this study, low leptin levels can be explained by inadequate thyroid hormones synthesis in surgically hypothyroid and hypothyroid with diabetes group. In these animals, serum leptin levels were significantly lower in both groups compared to diabetes group.

Thus, our results suggest that diabetes-induced hypothyroidism may contribute to antioxidant enzyme alterations in diabetic rats. However, the decrease in thyroid hormone levels due to diabetes seems to have no influence on lipid peroxidation changes in these rats. In the absence of thyroid hormones, insulin may not work as sufficiently as expected to control and balance the effects of oxidative stress on protein, lipids, and DNA. As a result, insulin and thyroid hormones must work together. In conclusion, during diabetic hypothyroidism, insulin is not sufficient to balance the metabolic pathways, thus the mediated effects of 
insulin on free radicals and antioxidant regulation via thyroid hormones are an increased possibility. In diabetes it might be that the changes of radical enzyme and antioxidant activities come into existence through different mechanisms or the possibility of affecting both insulin and thyroid hormones through increasing the gene transcriptions.

\section{References}

1. McCord JM, Fridovich I. The biology and pathology of oxygen radicals. Ann Int Med 1978; 89: 122-127.

2. Wolf SP, Jiang ZY, Hunt JV. Protein glycations and oxidative stress in diabetes mellitus and ageing. Free Radic Biol Med 1991; 10 (5): 339-352.

3. Kosova F, Altan N, Bugdayci G. Effects of the sulfonylurea glyburide on catalase activities in streptozotocin-induced diabetic rat muscle. The med J Kocatepe, Ocak 2006; 6: 41-44.

4. Wohaieb SA, Godin DV. Alterations in Free Radical Tissue- Defense Mechanisms in Streptozocin- Induced Diabetes in Rat. Diabetes 1987; 36: 1014-1018.

5. Godin DV, Wohaieb SA, Garnett ME, Goumeniouk AD. Antioxidant enzyme alterations in experimental diabetes. Mol Cell Biochem 1988; 84: 223-231.

6. Bukan N, Sancak B, Bilgihan A, Kosova F, Bugdayci G, Altan N. The effects of the sulfonylurea glyburide on glutathion peroxidase, superoxide dismutase and catalase activities in the heart tissue of streptozotocin-induced diabetic rat. Methods Find Exp Clin Pharmacol 2004; 26 (7): 519-522.

7. Altan N, Ongun CO, Elmali E, Kilic N, Yavuz O, Cayci B. Effect of the sulfonylurea glyburide on glutathione and glutathione peroxidase activity in alloxan induced diabetic rat hepatocytes. Gen Pharmac 1994; 25: $875-878$.

8. Giugliano D, Ceriello A, Paolisso G. Oxidative stress and diabetic vascular complications, Diabetes Care, 1996, 19: 257-66.

9. Elmali E, Altan N, Bukan N. Effect of the sulphonylurea glibenclamide on liver and kidney antioxidant enzymes in streptozotocin-induced diabetic rats. Drugs RD 2004; 5 (4): 203-208.

10. Bukan N, Sancak B, Yavuz O, Koca C, Kosova Tutkun F, Ozcelikay TA, Altan N. Lipid peroxidation and scavenging enzyme levels in the liver of streptozotocin-induced diabetic rats. Indian J Biochem Bioph 2003; 40: 447-450.

11. Takiguchi Y, Satoh N, Hashimoto H, Nakashima M. Reversal effect of thyroxine on altered vascular reactivity in diabetic rats. J Cardiovasc Pharmac 1989; 13: 520-524.

12. Altan N, Altan M, Mikolay L, Larner J, Schwartz CFW. Insülin-like and insülin enhancing effects of the sulfonylurea glyburide on rat adipose glycogen synthase. Diabetes 1985; 34: 281-286.

13. Lowry OH. Protein measurement with the folin reagent. J Biol Chem 1951; 193: 265-275.

14. Yi-Sun, Oberley LW, Li Y. A simple method for clinical assay of superoxide dismutase. Clin Chem 1988; 34 (13): 497-500.
15. Paglia DE, Valentine WN. Studies on the quantitative and qualitative characterization of erythrocyte GPx. J Lab Clin Invest 1967; 70 (1): 158-169.

16. Aebi H. Catalase in vitro. Methods Enzymol 1984; 105: 121-126.

17. Uchiyama M, Miheran M. Determination of Malondialdehyde precursor in tissue by thiobarbituric acid test. Ann Biochem 1978; 86: 271-278.

18. Hermes-Lima M, Willmore W, Storey KB. Quantification of lipid peroxidation in tissue extracts based on $\mathrm{Fe}(\mathrm{III})$ xylenol orange complex formation. Free Rad Biol Med 1995; 19 (3): 271-280.

19. Bugdayci G, Altan N, Sancak B, Bukan N, Kosova F. The effects of the sulfonylurea glyburide on glutathione- $\mathrm{S}$ transferase and glucose6-phosphate dehydrogenase in streptozotocin-induced diabetic rat liver. Acta Diabetol 2006; 43: 131-134.

20. Karasu C, Ozturk Y, Altan N, Ari N, Ikizler C, Altan M. Thyroid hormones mediated effect of insülin on alloxan diabetic rat atria. Gen Pharmac 1990; 21 (5): 735-740.

21. Stoppa GR, Cesquini M, Roman EAFR, Ogo SH, Torsoni AM. Aminoguanidine prevented impairment of blood antioxidant system in insülin-dependent diabetic rats. Life Sci 2005; 10-9.

22. Asayama K, Yokota S, Kato K. Peroximasol oxidase in various tissues of diabetic rats. Diabetes Res Clin Pract 1991; 11 (2): 89-94.

23. Horie $\mathrm{S}$, Ischii H, Suga $\mathrm{T}$. Changes in peroxisomal fatty acid oxidation in the diabetic rat liver. J Biochem 1981; 90: 1961-1996.

24. Jones DP, Eklöw L, Thor H, Orrenius S. Metabolism of hydrogen peroxide in isolated hepatocytes: relative contributions of catalase and glutathione peroxidase in decomposition of endogenously generated $\mathrm{H}_{2} \mathrm{O}_{2}$. Arch Biochem Biophys 1981; 210 (2): 505-516.

25. Nichollis P. Contributions of catalase and glutathione peroxidase to red cell peroxide removal. Biochim Biophys Acta 1972; 279 (2): 306-309.

26. Kosova F, Cetin B, Akinci M, Aslan S, Ari Z, Sepici A, Altan N, Cetin A. Advanced Oxidation Protein Products, Ferrous oxidation in xylenol orange and Malondialdehyde Levels in Thyroid Cancer. Ann Surg Oncol 2007; 14 (9): 2616-2620.

27. Halliwell B, Clement MV, Long LH. Hydrogen peroxide in the human body. Febs Lett 2000; 486: 10-12.

28. Ganapathy S, Ponnusamy P. Antidiabetic effect of S-allylcysteine: Effect on Thyroid hormone and circulatory antioxidant system in experimental diabetic rats. J Diabet Compl 2000.

29. Wolf SP. Ferrous ion oxidation in presence of xylenol orange for measurement of hydroperoxides. Methods Enzymol 1984; 223: 182-189.

30. Rodgers CD, Noble EG, Taylor AW. The effect of STZ induced diabetes on serum triiodothyronine (T3) and thyroxine (T4) levels in the rat: a seven week time course. Diabetes Res 1994; 26: 93-100.

31. Altan N, Sepici-Dincel A, Sahin D, Kocamanoglu N, Kosova F, Engin A. Oxidative DNA damage: the thyroid hormone-mediated effects of insulin on liver tissue. Endocr 2010; 38: 214-220.

32. Kosova F, Sepici-Dincel A, Engin A, Memis L, Koca C, Altan N. The thyroid hormone mediated effects of insulin on serum leptin levels of diabetic rats. Endocr 2008; 33: 317-322.

Received February 13, 2012. Accepted January 20, 2013. 